\title{
High-quality total RNA isolation from melon (Cucumis melo L.) fruits rich in polysaccharides
}

\section{Isolamento de RNA total de alta qualidade a partir de frutos de melão (Cucumis melo L.) contendo altos níveis de polissacarídeos}

\author{
Gabrielle Silveira de Campos ${ }^{1}$; Ricardo Antônio Ayub ${ }^{2 *}$; Rafael Mazer Etto ${ }^{3}$; \\ Carolina Weigert Galvão ${ }^{4}$; Marília Aparecida Stroka ${ }^{5}$ Juliana Inaba ${ }^{3}$
}

\begin{abstract}
Melon, a member of the family Cucurbitaceae, is the fourth most important fruit in the world market and, on a volume basis, is Brazil's main fresh fruit export. Many molecular techniques used to understand the maturation of these fruits require high concentrations of highly purified RNA. However, melons are rich in polyphenolic compounds and polysaccharides, which interfere with RNA extraction. This study aimed to determine the most appropriate method for total RNA extraction from melon fruits. Six extraction buffers were tested: T1) guanidine thiocyanate/phenol/chloroform; T2) sodium azide/ $\beta$ mercaptoethanol; T3) phenol/guanidine thiocyanate; T4) CTAB/PVP/ $\beta$-mercaptoethanol; T5) SDS/ sodium perchlorate/PVP/ $\beta$-mercaptoethanol, and T6) sarkosyl/PVP/guanidine thiocyanate, using the AxyPrep $^{\mathrm{TM}}$ Multisource Total RNA Miniprep Kit. The best method for extracting RNA from both mature and green fruit was based on the SDS/PVP/ $\beta$-mercaptoethanol buffer, because it rapidly generated a high quality and quantity of material. In general, higher amounts of RNA were obtained from green than mature fruits, probably due to the lower concentration of polysaccharides and water. The purified material can be used as a template in molecular techniques, such as microarrays, RT-PCR, and in the construction of cDNA and RNA-seq data.
\end{abstract}

Key words: RNA extraction methods. RNA quality. Melon.

\section{Resumo}

O melão pertencente à família Cucurbitaceae é o quarto fruto mais importante no mercado mundial e a fruta mais exportada pelo Brasil. Muitas técnicas moleculares utilizadas para compreender a maturação destes frutos requerem o uso de RNA altamente purificado e em alta concentração. Entretanto, o elevado nível de compostos polifenólicos e polissacarídeos nos frutos tornam a extração de RNA um desafio. Este trabalho teve por objetivo determinar o método mais adequado para extração de RNA total em frutos de melão. Seis diferentes tampões de extração foram testados: T1) tiocianato de guanidina/ fenol/clorofórmio; T2) azida de sódio/ $\beta$-mercaptoetanol; T3) fenol/tiocianato de guanidina, T4) CTAB/ PVP//-mercaptoetanol, T5) SDS/perclorato de sódio/PVP/ $\beta$-mercaptoetanol e T6) sarcosil/PVP/ tiocianato de guanidina associado com AxyPrep TM Multisource Total RNA Miniprep Kit. O melhor método para extração do RNA tanto de fruto verde quanto maduro foi o baseado no tampão SDS/

\footnotetext{
${ }^{1}$ Discente, Curso de Graduação em Farmácia, UEPG, Ponta Grossa, PR, Brasil. E-mail: gabriellesilveiradecampos@yahoo.com.br

2 Prof. Associado, Universidade Estadual de Ponta Grossa, UEPG, Departamento de Fitotecnia, Ponta Grossa, PR, Brasil. E-mail: rayub@uepg.br

3 Profs., Adjunto, UEPG, Departamento de Química, Ponta Grossa, PR, Brasil. E-mail: mazeretto@uepg.br; juinaba@hotmail.com

${ }^{4}$ Prof ${ }^{a}$ Adjunta, UEPG, Departamento de Biologia Estrutural, Molecular e Genética, Ponta Grossa, PR, Brasil. E-mail: carolwgalvao@yahoo.com.br

${ }^{5}$ Discente, Curso de Graduação em Agronomia, UEPG, Ponta Grossa, PR, Brasil. E-mail: mariliastroka.agro@hotmail.com

* Author for correspondence
} 
$\mathrm{PVP} / \beta$-mercaptoetanol, por gerar material íntegro e de qualidade em grande quantidade, associado à rapidez de execução. Em geral, maiores quantidades de RNA foram obtidas a partir de frutos verdes, provavelmente devido à baixa concentração de polissacarídeos e água. O material purificado poderá ser utilizado como molde em técnicas de estudos moleculares como microarrays, RT-PCR e bibliotecas de cDNA e RNAseq, pelo qual foi testado.

Palavras-chave: Metodologias de extração de RNA. Qualidade do RNA. Melão.

Melon (Cucumis melo L.) belongs to the family Cucurbitaceae. It is the fourth most important fruit in the world market and, in terms of volume, is Brazil's main fresh fruit export (ANUÁRIO BRASILEIRO DA FRUTICULTURA, 2015). The taste and quality of the fruit depend on the physiological and biochemical variations that occur during its development and maturation (NUNEZ-PALENIUS et al., 2008). These physiological changes are the result of the transcriptional modulation of several genes. Thus, their understanding requires the use of molecular biology techniques, such as microarray assays, subtractive hybridization and RNA-Seq, which necessitate the extraction of high-quality total RNA. However, the isolation of total RNA from some plants is difficult due to the presence of high concentrations of secondary metabolites, such as polysaccharides and polyphenolic compounds, which may precipitate or interact with ribonucleic acids (ZAMBONI et al., 2008). Strawberry and grape tissues are rich in polyphenolic compounds and polysaccharides, therefore, the isolation of highquality RNA in acceptable yields, particularly from their flesh tissues, is often a challenge (CHRISTOU et al., 2014; VASANTHAIAH et al., 2008).

Although there are many RNA protocols specific to plants with a high content of phenolic compounds, they typically involve an extensive preparation time and do not apply to all types of fruits (KALINOWSKA et al., 2012). In addition, for plants rich in secondary metabolites, isolation of the RNA using commercial kits is often unsatisfactory and does not produce acceptable yields. In particular, the isolation and purification of RNA from fruits is hindered by the presence of abundant compounds (polysaccharides, polyphenols, proteins and genomic DNA contamination) that interact with nucleic acids, forming insoluble co-precipitates (CHRISTOU et al., 2014). RNA isolation also depends on other critical factors, such as the inactivation of endogenous and exogenous RNAs that promote the degradation of the purified material. Many methods for RNA isolation use strong denaturants, such as guanidine salts to simultaneously disrupt cellular activity, solubilize their components and denature RNAs, which affect the quality of the process (MACKENZIE et al., 1997). Furthermore, despite the numerous RNA isolation protocols that exist, there is no universal method for all species of plants or plant organs. Even identical tissues, at different stages of development, may require a specific RNA isolation protocol due to their variable chemical compositions (SHARMA et al., 2003).

In this context, the current study evaluated six methods of RNA extraction, comparing the integrity, quantity and quality of the total RNA extracted from two cultivars of $C$. melo L. var. Inodorus. (Eldorado 300 and Pele de Sapo cultivars) cultivated in Ponta Grossa, Paraná, Brazil. The fruits were harvested in green and ripe stages, cut, immediately frozen in liquid nitrogen and stored at $-80^{\circ} \mathrm{C}$. The glassware, porcelain and stainless steel materials were presterilized at $180{ }^{\circ} \mathrm{C}$ for $6 \mathrm{~h}$ and the plastic materials treated with diethylpyrocarbonate (DEPC) and autoclaved.

The six methods of RNA extraction were as follows:

1) Guanidine thiocyanate/phenol/chloroform: this method is used for animal, plant and bacterial cells. An aliquot $(0.1 \mathrm{~g})$ of crushed tissue was treated using the TRIzol ${ }^{\circledR}$ Plus RNA Purification Kit buffer (Invitrogen, Carlsbad/California/USA), according to the manufacturer's recommendations. 
2) Sodium azide/ $\beta$-mercaptoethanol: this method applies to plant tissues rich in polyphenolic compounds and starch. An aliquot $(0.1 \mathrm{~g})$ of crushed tissue was used in combination with the Concert Plant RNA Reagent (Invitrogen), according to the manufacturer's recommendations.

3) Phenol/guanidine thiocyanate: a method used for animal, plant and bacterial cells. An aliquot ( 0.1 g) of triturated tissue was used in combination with the TriPure Isolation Reagent Kit (Sigma-Aldrich, St. Louis/Missouri/USA) buffer, according to the manufacturer's recommendations.

4) Cetyltrimethylammonium bromide (CTAB)/ polyvinylpyrrolidone (PVP)/ $\beta$-mercaptoethanol: method indicated for strawberry tissue (Fragaria $\times$ ananassa), according to $\mathrm{Yu}$ et al. (2012) (3\% CTAB, $100 \mathrm{mM}$ Tris-HCl, pH 8.0, $1.4 \mathrm{M} \mathrm{NaCl}$, $20 \mathrm{mM}$ EDTA, 5\% PVP e 1\% $\beta$-mercaptoetanol) were added to a sterile tube containing $700 \mu \mathrm{l}$ of extraction buffer (PVP and 1\% $\beta$-mercaptoethanol), homogenized and incubated at $60{ }^{\circ} \mathrm{C}$ for $10 \mathrm{~min}$. The sample was centrifuged at 15,700 g for $5 \mathrm{~min}$. The supernatant was collected and an equal volume of chloroform:isoamyl alcohol (24:1) was added, homogenized for $1 \mathrm{~min}$ and centrifuged at 15,500 $\mathrm{g}$, at room temperature, for $10 \mathrm{~min}$. The supernatant was again collected, treated with an equal volume of chloroform, and homogenized and centrifuged under the same conditions. The supernatant was transferred to a tube with an equal volume of $4 \mathrm{M}$ $\mathrm{LiCl}$ and precipitated at $4{ }^{\circ} \mathrm{C}$ for $4 \mathrm{~h}$. The sample was then centrifuged at $15,500 \mathrm{~g}$, at $4{ }^{\circ} \mathrm{C}$, for 15 min, the supernatant washed with $75 \%$ ethanol and separated by centrifugation at $6000 \mathrm{~g}$ for $5 \mathrm{~min}$. This procedure was repeated and the precipitate was dried in a vacuum pump and then eluted in $30 \mu \mathrm{l}$ RNase-free MilliQ water.

5) Sodium dodecyl sulfate (SDS)/sodium perchlorate/PVP/ $\beta$-mercaptoethanol: indicated for grape tissues (Vitis vinifera L. cv. Shiraz), as described by Boss et al. (1996), with slight modifications. A 4-g aliquot of tissue was crushed in liquid nitrogen and transferred to a tube with $16 \mathrm{~mL}$ of the extraction buffer $(0.3 \mathrm{M}$ Tris- $\mathrm{HCl}$, $\mathrm{pH} 8.3,2 \%$ PEG 4000, $5 \mathrm{M}$ sodium perchlorate, $1 \%$ SDS, $8.5 \%$ PVP, $1 \% \quad \beta$-mercaptoethanol), homogenized and incubated at room temperature for $30 \mathrm{~min}$. The solution was transferred to a column containing cotton and centrifuged at $200 \mathrm{~g}$, at $4{ }^{\circ} \mathrm{C}$, for $15 \mathrm{~min}$. The eluted fraction was treated with 2.5 volumes of ethanol at $-20^{\circ} \mathrm{C}$, for $40 \mathrm{~min}$, followed by centrifugation at $7700 \mathrm{~g}$, at $4{ }^{\circ} \mathrm{C}$, for 25 min. The precipitate was washed with $70 \%$ ethanol, dried under vacuum and resuspended in $1 \mathrm{~mL}$ Tris-EDTA $(0.1 \mathrm{mM}$ Tris/ $1 \mathrm{mM}$ EDTA, $\mathrm{pH}$ 7.6) and $0.2 \%\left(\mathrm{v} \mathrm{v}^{-1}\right) \beta$-mercaptoethanol. Then, it was washed three times with an equal volume of phenol:chloroform:isoamyl alcohol $(25: 24: 1)$ and a volume of chloroform:isoamyl alcohol solution (24:1), followed by centrifugation at $3200 \mathrm{~g}$ for 5 $\min$ and $12,000 \mathrm{~g}$ for $2 \mathrm{~min}$. The RNA was treated with 0.1 volumes of $3 \mathrm{M}$ sodium acetate solution and 2.5 volumes of $95 \%$ ethanol and incubated at $-20{ }^{\circ} \mathrm{C}$, for $20 \mathrm{~min}$. It was then centrifuged at 12,000 $\mathrm{g}$ at $4{ }^{\circ} \mathrm{C}$ for $10 \mathrm{~min}$, washed with $1 \mathrm{ml}$ of $70 \%$ ethanol and dried under vacuum. The precipitate was resuspended in $100 \mu \mathrm{L}$ of RNAse-free water.

6) Sarkosyl/PVP/guanidine thiocyanate, in combination with the AxyPrep ${ }^{\mathrm{TM}}$ Multisource Total RNA Miniprep Kit (Axygen, Corning/New York/USA). This method is indicated for woody plants with tissues rich in polysaccharides and polyphenolic compounds (MACKENZIE et al., 1997): A $1.1 \mathrm{~g}$ aliquot of tissue was crushed in liquid nitrogen and added to $14 \mathrm{~mL}$ of extraction buffer containing $4 \mathrm{M}$ guanidine isothiocyanate, $0.2 \mathrm{M}$ sodium acetate, $\mathrm{pH}$ 5, $0.25 \mathrm{mM}$ EDTA, 5\% $\left(\mathrm{m} \mathrm{v}^{-1}\right)$ PVP 40 and $1 \%\left(\mathrm{~m} \mathrm{v}^{-1}\right) \beta$-mercaptoethanol. Then, $100 \mu \mathrm{L}$ of $20 \%$ sarkosyl solution was added. The mixture was incubated in a water bath at 65 ${ }^{\circ} \mathrm{C}$ for $5 \mathrm{~min}$, and then added to a $30-\mathrm{mL}$ cottoncontaining column. The sample was centrifuged at $156 \mathrm{~g}$ at $4{ }^{\circ} \mathrm{C}$ for $15 \mathrm{~min}$ and the supernatant treated with 2.5 volumes of absolute ethanol at $-20{ }^{\circ} \mathrm{C}$ for $20 \mathrm{~min}$. The sample was centrifuged at $3220 \mathrm{~g}$, at 
$4{ }^{\circ} \mathrm{C}$ for $20 \mathrm{~min}$, the pellet washed with $500 \mu \mathrm{l}$ of $70 \%$ ethanol, centrifuged at $3220 \mathrm{~g}$ for $10 \mathrm{~min}$ and resuspended in $500 \mu 1$ Tris-EDTA buffer, containing $0.2 \% \beta$-mercaptoethanol. The solution was treated with $500 \mu \mathrm{L}$ phenol:chloroform:isoamyl alcohol (25:24:1) and centrifuged at $4500 \mathrm{~g}$ for $2 \mathrm{~min}$. The liquid phase was again treated and centrifuged at $4500 \mathrm{~g}$ for $4 \mathrm{~min}$. The upper layer was removed and treated with 0.1 volume of $3 \mathrm{M}$ sodium acetate, $\mathrm{pH} 5.2$ and 2.5 volumes of absolute ethanol at -20 ${ }^{\circ} \mathrm{C}$ for $12 \mathrm{~h}$. Thereafter, the sample was centrifuged at $7700 \mathrm{~g}$, at $4{ }^{\circ} \mathrm{C}$, for $15 \mathrm{~min}$ and the precipitate was dried under vacuum for $1 \mathrm{~h}$ and resuspended in $100 \mu \mathrm{L}$ of RNAse-free water. Finally, the material was purified using the AxyPrep ${ }^{\mathrm{TM}}$ Multisource RNA total Miniprep Kit, as per the manufacturer's recommendations.

After extraction, the integrity, amount and quality of purified total RNA were analyzed. The integrity was evaluated by electrophoresis in 1.0\% agarose gel, run at $60 \mathrm{~V}$ for $1 \mathrm{~h}$. Afterward, the agarose gel was stained with ethidium bromide (5 $\mu 1 \mathrm{~mL}^{-1}$ ) for $20 \mathrm{~min}$, exposed to ultraviolet (UV) light and digitalized by photodocumentation (Vilber Lourmat, Collégien/France). The concentration of the ribonucleic acids was measured by fluorimetry (Qubit, Invitrogen) and the purity of the extracted total RNA was determined by spectrophotometry, through absorbance ratios $A_{260 \mathrm{~nm}} / \mathrm{A}_{280 \mathrm{~nm}}$ and $\mathrm{A}_{260}$ ${ }_{\mathrm{nm}} / \mathrm{A}_{230 \mathrm{~nm}}$ (NanoVue, GE Healthcare Life Sciences/ São Paulo/Brazil). An $\mathrm{A}_{260 \mathrm{~nm}} / \mathrm{A}_{280 \mathrm{~nm}}$ ratio below 2.0, suggests that purified RNA may be contaminated with proteins, phenolic compounds or other contaminants with $\mathrm{UV}$ absorption at $280 \mathrm{~nm}$. An $\mathrm{A}_{260}$ ${ }_{\mathrm{nm}} / \mathrm{A}_{230 \mathrm{~nm}}$ ratio below 2.0, suggests contamination with carbohydrates, phenolic compounds, EDTA and other contaminants with a UV absorption at $230 \mathrm{~nm}$ (MANNING, 1991; LOGEMANN et al., 1987). Table 1 shows the results obtained from the total RNA extraction. The extraction efficiency was determined by dividing the mass of total RNA obtained from the extraction (ng) by the mass of the fruit sample $(\mathrm{g})$.

Table 1. Quantification of the total RNA extracted from melons with the efficiency calculated from the fresh mass of the sample in $(\mathrm{g})$.

\begin{tabular}{|c|c|c|c|c|c|c|c|}
\hline $\begin{array}{l}\text { Method/ } \\
\text { Runtime (h) }\end{array}$ & Cultivar & Stage & $\begin{array}{l}\text { Concen- } \\
\text { tration } \\
\left(\mathrm{ng} \mu \mathrm{L}^{-1}\right) \\
\end{array}$ & $\begin{array}{c}\text { Efficiency } \\
\text { (ng RNA } \\
\mathrm{g}^{-1} \text { fruit) } \\
\end{array}$ & $\begin{array}{c}\mathrm{A}_{260} \\
\mathrm{~nm} / 280 \mathrm{~nm} \\
\end{array}$ & $\begin{array}{c}\mathrm{A}_{260} \\
\mathrm{~nm} / 230 \mathrm{~nm} \\
\end{array}$ & $\begin{array}{c}\text { Corresponding } \\
\text { sample number } \\
\text { in Figure } 1 \\
\end{array}$ \\
\hline \multirow[b]{2}{*}{ T1) TRIzol (4 h) } & Eldorado & Ripe & 140.0 & 28000 & 1.712 & 0.232 & 1 \\
\hline & Pele de Sapo & Ripe & $<20.0$ & $<4000$ & 1.644 & 0.329 & 2 \\
\hline \multirow{3}{*}{$\begin{array}{l}\text { T2) Concert Plant } \\
\text { (4 h) }\end{array}$} & \multirow{2}{*}{ Eldorado } & Green & 85.2 & 25560 & 2.029 & 4.347 & 3 \\
\hline & & Ripe & 44.8 & 13440 & 2.095 & 0.338 & 4 \\
\hline & Pele de Sapo & Ripe & 83.2 & 24960 & 2.5 & 0.323 & 5 \\
\hline \multirow{3}{*}{$\begin{array}{l}\text { T3) TriPure } \\
\text { (4 h) }\end{array}$} & \multirow{2}{*}{ Eldorado } & Green & 78.4 & 15680 & 1.654 & 0.328 & 6 \\
\hline & & Ripe & 130.0 & 26000 & 1.84 & 0.138 & 7 \\
\hline & Pele de Sapo & Ripe & 59.6 & 11920 & 1.784 & 0.282 & 8 \\
\hline \multirow{2}{*}{$\begin{array}{l}\text { T4) Yu et al. (2012) } \\
\text { (6 h) }\end{array}$} & Eldorado & Ripe & $<20.0$ & $<6000$ & 1.533 & 0.268 & 9 \\
\hline & Pele de Sapo & Ripe & 7.46 & 2238 & 1.74 & 0.108 & 10 \\
\hline \multirow{2}{*}{$\begin{array}{l}\text { T5) Boss et al. (1996) } \\
(8 \mathrm{~h})\end{array}$} & \multirow{2}{*}{ Eldorado } & Green & 184.0 & 4600 & 1.898 & 2.251 & 11 \\
\hline & & Ripe & 133.0 & 3325 & 1.994 & 1.697 & 12 \\
\hline \multirow{3}{*}{$\begin{array}{l}\text { T6) MacKenzie et al. } \\
\text { (1997) (13 h) }\end{array}$} & \multirow{2}{*}{ Eldorado } & Green & 584.0 & 37163 & 2.071 & 2.012 & 13 \\
\hline & & Ripe & 110.0 & 7000 & 2.165 & 2.115 & 14 \\
\hline & Pele de Sapo & Ripe & 79.8 & 5078.2 & 1.947 & 0.847 & 15 \\
\hline
\end{tabular}


The best method for extracting melon RNA was the T5 method, using SDS/sodium perchlorate/ PVP/ $\beta$-mercaptoethanol. The presence of sodium perchlorate was shown to be important in removing SDS and complexing with contaminating proteins (WILCOCKSON, 1973), improving the purity of the extracted RNA. The quality of the extracted material can be observed in Figure 1 (gel bands corresponding to samples 14 and 15), where the bands corresponding to the $18 \mathrm{~S}$ and $28 \mathrm{~S}$ RNA are evident. The T3 isolation method, based on phenol/ guanidine thiocyanate, also showed good results. The presence of phenol, a denaturing organic solvent, separated the RNA from the contaminating proteins. However, the presence of phenol in the composition can damage the poly-A tail of the extracted mRNA (AZEVEDO et al., 2003), being a possible cause of low $A_{260 \mathrm{~nm}} / \mathrm{A}_{230 \mathrm{~nm}}$ ratio (Table 1), impairing the use of this material in molecular techniques, such as RT-PCR.

Figure 1. Evaluation by agarose (1\%) gel electrophoresis of the integrity of total RNA extracted from Eldorado (ELD) and Pele de Sapo (PS) melons at the mature (M) and green (V) developmental stages, using six methods of extraction. Sample no: 1) TRIzol, ELD-M; 2) TRIzol, PS-M; 3) Concert Plant, ELD-V; 4) Concert Plant, ELD-M; 5) Concert Plant, PS-M; 6) TriPure, ELD-V; 7) TriPure, ELD-M; 8) TriPure, PS-M; 9) Yu et al. (2012), ELD-M; 10) Yu et al. (2012), PS-M; 11) Boss et al. (1996), ELD-V; 12) Boss et al. (1996), ELD-M; 13) Mackenzie et al. (1997), ELD-V; 14) Mackenzie et al. (1997), ELD-M; 15) Mackenzie et al. (1997), PS-M; M1, molecular weight marker of 100 bp, and M2, molecular weight marker of $1 \mathrm{~Kb}$ (Axygen, Corning/New York/USA).

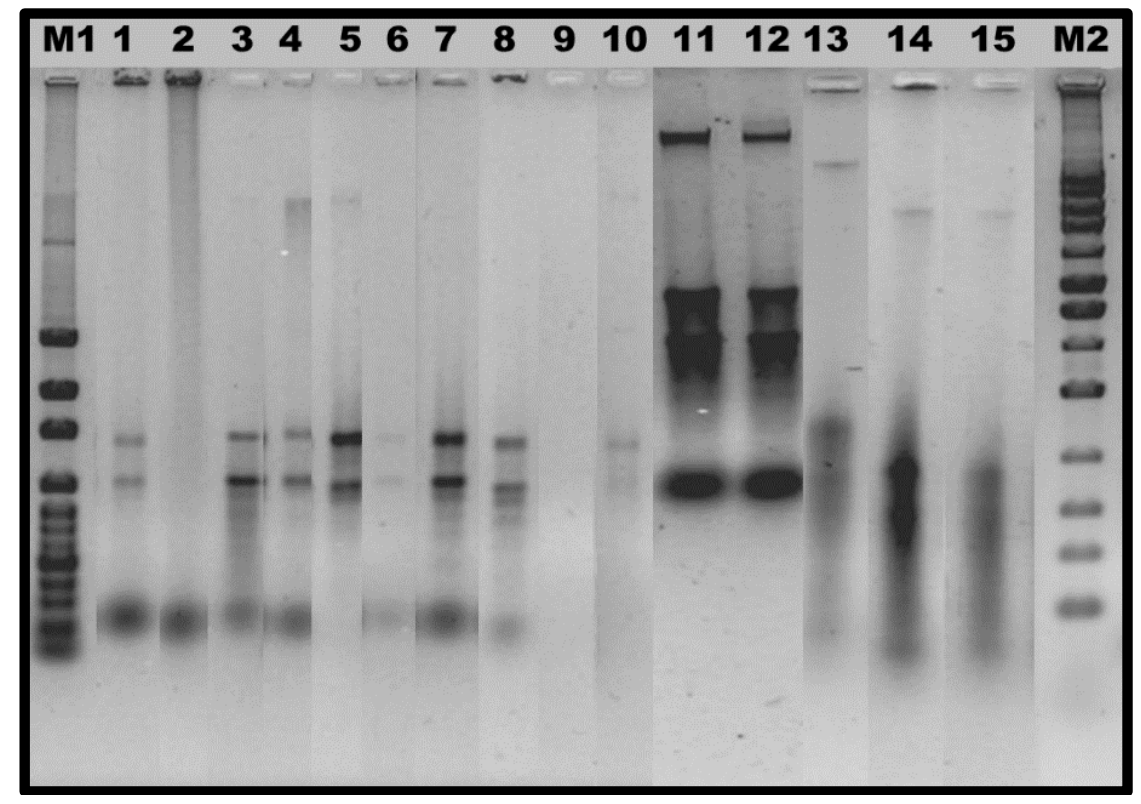

The T4 method resulted in a low RNA concentration and a low efficiency (Figure 1, gel bands corresponding to samples 9 and 10). The T6 method, which involved the AxyPrep ${ }^{\mathrm{TM}}$ Multisource Total RNA Miniprep Kit, showed a moderate total RNA extraction efficiency (between 7000-3700 ng). However, ribonucleic acids were degraded (Figure 1, gel bands corresponding to samples 11, 12 and 13). This is among the most widely used methods for RNA extraction, due to its simplicity and efficiency (RAMCHANDRA; STURM, 2010; CORBACHO et al., 2013; CHEN et al., 2016; ZHANG et al., 2016). However, in our study, the extracted material presented a low $\mathrm{A}_{260 \mathrm{~nm}} / \mathrm{A}_{230 \mathrm{~nm}}$ ratio, indicating the presence of contaminating polysaccharides or polyphenols in both the green and mature fruits. Another critical factor is the high cost of the reagent, which makes RNA extraction 
from large samples very expensive (DINKINS et al., 2010).

Regarding the efficiency, the best protocols were T2, T3 and T6 in the green stage of the Eldorado cultivar but the T2 and T3 methods resulted in very low $A_{260 \mathrm{~nm}} / A_{230 \mathrm{~nm}}$ ratios (Table 1). The best absorbance ratios were obtained with the T5 and T6 methods. However, when comparing the electrophoresis gel results, the T5 method was the best because it did not present degraded RNA (Figure 1, gel bands corresponding to samples 14 and 15), unlike the T6 method (Figure 1, gel bands corresponding to samples 11, 12 and 13).

Thus, the T5 method, originally designed for RNA extraction from grapes, is also indicated for the extraction of total RNA from C. melo L., at both stages of maturation, using a large sample of fruit (4 g) and generating an acceptable yield of high-quality RNA. The method used by Boss et al. (1996) was slightly modified, regarding incubation time (from $20 \mathrm{~min}$ to $40 \mathrm{~min}$ ) and centrifugation intensity (from $7700 \mathrm{~g} / 25 \mathrm{~min}$ to $3220 \mathrm{~g} / 15 \mathrm{~min}$ ), during the ethanol precipitation step.

Considering the maturation stages of the melons, the green stages had the highest concentrations of total RNA (ng $\mu \mathrm{L}^{-1}$ ), probably because the immature fruits have lower amounts of sugars and water (NUNEZ-PALENIUS et al., 2008). Hence, the results show that it is possible to purify highquality RNA from melon fruits. Also, because of the high quality and large amount of purified RNA, the T5 method can be used in molecular studies of gene expression, such as RT-PCR, microarrays, and preparation of cDNA and RNA-seq data. Thus, the following conclusions can be drawn from this study:

1. In general, higher amounts of RNA were obtained from green (immature) fruits. The lower content of polysaccharides and water in these fruits compared to the mature fruits, may have favored the efficiency of RNA purification from the immature melons.
2. The reduced number of steps required for RNA extraction using commercial kits, may be responsible for their increased integrity.

3. The best method for extracting total RNA from $C$. melo in the green and mature stage was SDS/PVP/B-mercaptoethanol (BOSS et al., 1996), which produced total RNA of good integrity and in acceptable quantity, as tested by RNA-seq analyzes (data not shown).

\section{Acknowledgements}

The authors express their gratitude to the CNPq, Capes and Araucária Foundation of the State of Paraná for their financial support.

\section{References}

ANUÁRIO BRASILEIRO DA FRUTICULTURA. Melão: grandes voos. Santa Cruz do Sul: Editora Gazeta, 2015. $33 \mathrm{p}$.

AZEVEDO, H.; LINO-NETO, T.; TAVARES, R. M. An improved method for high-quality RNA isolation from needles of adult maritime pine trees. Plant Molecular Biology Reporter, Athens, v. 21, n. 4, p. 333-338, 2003.

BOSS, P. K.; DAVIES, C.; ROBINSON, S. P. Analysis of the expression of anthocyanin pathway genes in developing Vitis vinifera L. cv Shiraz grape berries and the implications for pathway regulation. Plant Physiology, Adelaide, v. 111, n. 4, p. 1059-1066, 1996.

CHEN, H.; CAO, S.; JIN, Y.; TANG, Y.; QI, H. The relationship between $\mathrm{CmADHs}$ and the diversity of volatile organic compounds of three aroma types of melon (Cucumis melo). Frontiers in Physiology, Ohio, v. 7, n. 254, p. 1-12, 2016.

CHRISTOU, A.; GEORGIADOU, E. C.; FILIPPOU, P.; MANGANARIS, G. A.; FOTOPOULOS, V. Establishment of a rapid, inexpensive protocol for extraction of high quality RNA from small amounts of strawberry plant tissues and other recalcitrant fruit crops. Gene, Amsterdam, v. 537, n. 1, p. 169-173, 2014.

CORBACHO, J.; ROMOJARO, F.; PECH, J. C.; LATCHÉ, A.; GOMEZ-JIMENEZ, M. C. Transcriptomic events involved in melon mature-fruit abscission comprise the sequential induction of cell-wall degrading genes coupled to a stimulation of endo and exocytosis. PloS One, San Francisco, v. 8, n. 3, p. 1-19, 2013. 
DINKINS, R. D.; BARNES, A.; WATERS, W. Microarray analysis of endophyte-infected and endophyte-free tall fescue. Journal of Plant Physiology, Lexington, v. 167, n. 14, p. 1197-1203, 2010.

KALINOWSKA, E.; CHODORSKA, M.; PADUCHCICHAL, E.; MROCZKOWSKA, K. An improved method for RNA isolation from plants using commercial extraction kits. Acta Biochimica Polonica, Warsaw, v. 59, n. 3, p. 391-393, 2012.

LOGEMANN, J.; SCHELL, J.; WILLMITZER, L. Improved method for the isolation of RNA from plant tissues. Analytical Biochemistry, New York, v. 163, n. 1, p. 16-20, 1987.

MACKENZIE, D. J.; MCLEAN, M. A.; MUKERJI, S.; GREEN, M. Improved RNA extraction from woody plants for the detection of viral pathogens by reverse transcription-polymerase chain reaction. Plant Disease, St. Paul, v. 81, n. 2, p. 222-226, 1997.

MANNING, K. Isolation of nucleic acids from plants by differential solvent precipitation. Analytical Biochemistry, New York, v. 195, n. 1, p. 45-50, 1991.

NUNEZ-PALENIUS, H. G.; GOMEZ-LIM, M.; OCHOA-ALEJO, N.; GRUMET, R.; LESTER, G.; CANTLIFFE, D. J. Melon fruits: genetic diversity, physiology, and biotechnology features. Critical Reviews in Biotechnology, Irapuato, v. 28, n. 1, p. 13-55, 2008.

RAMCHANDRA, P.; STURM, A. W. Validation of RNA integrity from low yield experiments with Mycobacterium tuberculosis for downstream application in real time PCR. African Journal of Microbiology Research, KwaZuluNata, v. 4, n. 15, p. 1594-1598, 2010.
SHARMA, A. D.; GILL, P. K.; SINGH, P. RNA isolation from plant tissues rich in polysaccharides. Analytical Biochemistry, New York, v. 314, n. 2, p. 319-321, 2003.

VASANTHAIAH, H. K. N.; KATAM, R.; SHEIKH, M. B. Efficient protocol for isolation of functional RNA from different grape tissue rich in polyphenols and polysaccharides for gene expression studies. Electronic Journal of Biotechnology, Valparaíso, v. 11, n. 3, p. 4251, 2008.

WILCOCKSON, J. The use of sodium perchlorate in deproteinization during the preparation of nucleic acids. Biochemical Journal, Norwich, v. 135, n. 3, p. 559-561, 1973.

YU, D.; TANG, H.; ZHANG, Y.; DU, Z.; YU, H.; CHEN, Q. Comparison and improvement of different methods of RNA isolation from strawberry (Fragria $\times$ ananassa). Journal of Agricultural Science, Cambridge, v. 4, n. 7, p. 51-56, 2012.

ZAMBONI, A.; PIERANTONI, L.; DE FRANCESCHI, P. Total RNA extraction from strawberry tree (Arbutus unedo) and several other woody-plants. iForest Biogeosciences and Forestry, Bologna, v. 1, n. 4, p. 122125, 2008.

ZHANG, H.; WANG, H.; YI, H.; ZHAI, W.; WANG, G.; FU, Q. Transcriptome profiling of Cucumis melo fruit development and ripening. Horticulture Research, London, v. 3, n. 3, p. 1-10, 2016. 
